\title{
Monoblast to Leukocyte Ratio Measurement
}

National Cancer Institute

\section{Source}

National Cancer Institute. Monoblast to Leukocyte Ratio Measurement. NCI Thesaurus. Code C74646.

The determination of the ratio of monoblast cells compared to leukocytes present in a sample. The measurement may be expressed as a ratio or percentage. 